\title{
Indole butyric acid and substrates influence on multiplication of blackberry 'Xavante'
}

\author{
Influência do ácido indol butírico e substratos na propagação de amoreira-preta \\ 'Xavante'
}

\author{
Ibrar Hussain ${ }^{I}$ Adriane Marinho de Assis ${ }^{I I}$ Lilian Yukari Yamamoto ${ }^{\mathrm{I}}$ \\ Renata Koyama ${ }^{\mathrm{I}}$ Sérgio Ruffo Roberto ${ }^{\mathrm{III}}$
}

\section{ABSTRACT}

Blackberry is a shrubby plant specie which has a high economic importance among agriculture crops. Brazil is the major country of Latin America with the highest future scope for blackberries. For availability of good quality and maximum quantity of seedlings, the present study was carried out at the Universidade Estadual de Londrina,PR from January to March in 2013. The aim of the study was to evaluate the multiplication of blackberry 'Xavante' cuttings under different type of substrates treated with different levels of indole butyric acid (IBA). The experiment was laid out in randomized complete block design with 2 factors, i.e., substrate (rice husk, vermiculite and coconut fiber) and IBA ( 0 ; 1,000; 2,000 and 3,000mg $L^{-1}$ ), with 5 replications. Each replicate consisted of 10 cuttings. The variables studied were: cutting rooting, cutting survival, leaf retention, cuttings with new leaves, number of major roots, length of major roots and roots dry weight. Most of the variables were significantly affected by both substrate and IBA. Rice husk and vermiculite performed better than coconut fiber and provided the same results for most of the variables, while coconut fiber showed lower performance for all of the variables studied. IBA significantly affected the rooting and the number of major roots. It is concluded that for multiplication of blackberry 'Xavante', both rice husk and vermiculite can be used along 2,000mg L $L^{-1}$ of IBA.

Key words: indole butyric acid, vermiculite, coconut fiber.

\section{RESUMO}

A amoreira-preta é uma espécie vegetal arbustiva que apresenta relevante importância econômica entre as culturas frutíferas. O Brasil é o maior produtor da América Latina. Para disponibilidade de boa qualidade e alta quantidade de mudas, $o$ presente estudo foi realizado na Universidade Estadual de Londrina, PR, de janeiro a março, em 2013.O objetivo foi avaliar a mulitiplicação de amoreira-preta 'Xavante' em vários tipos de substratos sob diferentes níveis de ácido indol butírico (AIB). O delineamento experimental foi em blocos casualizados com dois fatores: substrato (casca de arroz carbonizada, vermiculita e fibra de coco) e AIB (0, 1.000, 2.000 e $\left.3.000 \mathrm{mg} \mathrm{L}^{-1}\right)$, com cinco repetições, sendo cada repetição constituída por 10 estacas. As variáveis avaliadas foram: estacas enraizadas, sobrevivência das estacas, retenção de folhas, estacas com folhas novas, número de raízes, comprimento de raízes e massa seca dos raízes. A maioria das variáveis foi significativamente afetada pelos substratos e AIB. A casca de arroz e vermiculita apresentaram melhor desempenho quanto à maioria das variáveis, enquanto a fibra de coco apresentou dempenho inferior. $O$ AIB afetou significativamente a porcentagem de enraizamento e o número de principais raízes. Conclui-se que, para a otimizar a multiplicação de mudas de amoreira-preta 'Xavante', tanto a casca de arroz carbonizada como a vermiculita podem ser usadas, associadas a $2.000 \mathrm{mg} \mathrm{L}^{-1}$ de AIB.

Palavras-chave: ácido indol butírico, vermiculita, fibra de coco.

\section{INTRODUCTION}

The blackberry (Rubus spp.), a shrubby plant specie of the family Rosaceae, is considered a good cultivation option for small scale growers because of low cost of development and maintenance of orchards, minimum level of insect and disease damage and higher nutritional value (ANTUNES et al., 2000; 2002). Mexico is the largest producer in the world with about 56,800 tons harvested in 2011, mainly for export (FAOSTAT, 2013). In Brazil, the main producing area is Rio Grande do Sul but other

IPrograma de Pós-graduação em Agronomia, Centro de Ciências Agrárias (CCA), Universidade Estadual de Londrina (UEL), Londrina, PR, Brasil.

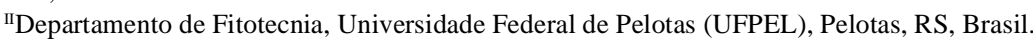

IIIDepartamento de Agronomia, UEL, CP 6001, 86051-990, Londrina, PR, Brasil. E-mail: sroberto@uel.br. Autor para correspondência. Received 09.09.13 Approved 02.17.14 Returned by the author 08.07.14 CR-2013-1204.R1 
regions with favorable microclimate, such as Minas Gerais, São Paulo, Santa Catarina and Paraná, have high potential for growing this specie (ANTUNES, 2002; VILLA et al., 2003).

Among the cultivars of blackberry, 'Xavante' has strong, erect and thornless stem, therefore needs no support, which facilitates the process of cultivation and harvesting (RASEIRA et al., 2004). It can be propagated by softwood cuttings, from woody roots, shoots and by tissue culture, which enables the achievement of large quantity seedlings in a short time (ANTUNES et al., 2004).

According FACHINELLO et al. (2005), the success of vegetative propagation through cuttings depends on the genetic potential of rooting, physiological conditions of the mother plant, season of year, hormonal balance, temperature, light and humidity.

The substrate varies for the germination process due to the factors such as structure, aeration capacity, water retention and degree of infestation of pathogens (POPINIGIS, 1977). Therefore, some techniques have been induced in order to provide increased emission of roots, and one of them is the use of plant growth regulators, such as indole butyric acid (IBA), a synthetic auxin enhancing root initiation which increases the percentage of rooting, number and quality of roots formed and uniform rooting (HAN et al., 2009).

KAMPF et al. (2006) reported that the process of root initiation of plant cuttings is related to the substrate, which influences the quality of roots formed and the percentage of rooting. It also prevents desiccation of the base of cuttings and possesses pore space which facilitates the availability of oxygen to the roots and doesn't have any phytotoxic substances for the plants (ANTUNES et al., 2004; FACHINELLO et al., 2005). Among the substrates commonly used for fruit plants propagation, some can be listed, such as vermiculite, rice husk and coconut fiber (ZIETEMANN \& ROBERTO, 2007).

Therefore, keeping in view the importance of both growth plant growth regulator and substrate for the propagation and development of new and healthy plants, the present study was conducted aiming to evaluate the use of different concentrations of IBA and substrates on cutting multiplication of blackberry 'Xavante' in order to optimize its nursery plant system.

\section{MATERIAL AND METHODS}

The experiment was carried out from January to March 2013 at Universidade Estadual de
Londrina - PR (altitude $23^{\circ} 23 \mathrm{~S}$, longitude $51^{\circ} 11 \mathrm{~W}$ and elevation of $566 \mathrm{~m})$. According to Köppen, the local climate is Cfa (subtropical humid). The genetic material of blackberry 'Xavante' was obtained from stock trees of EMBRAPA Clima Temperado, Pelotas, $\mathrm{RS}$ in 2011.

The experimental was laid out in randomized complete block design with five replications of ten cuttings per plot, in a $3 \times 4$ factorial arrangement. The factors were: three substrates (rice husk, vermiculite of medium granules and coconut fiber) and four concentrations of IBA $(0 ; 1,000 ; 2,000$ and 3,000mg L-1).

Before preparing the cuttings, a hydroalcoholic solution of IBA was obtained by weighting $0.1 \mathrm{~g}, 0.2 \mathrm{~g}$ and $0.3 \mathrm{~g}$ of IBA and dissolved into $50 \mathrm{~mL}$ of ethanol. After completely dissolved, the volume was raised to $100 \mathrm{~mL}$ with distilled water to obtain the concentrations of 1,000;2,000 and 3,000 $\mathrm{mg} \mathrm{L}^{-1}$ IBA, respectively (FACHINELLO et al., 2005).

Healthy shoots were selected and softwood cutting were prepared from middle portion of each shoot. The size of each cutting was of $10-12 \mathrm{~cm}$. The cuttings consisted of a cut just below a node, and the leaves near to the basal portion were removed, leaving a pair of leaves at the top. During preparation, the cuttings were placed in a water recipient to avoid dehydration. After preparation of cuttings, IBA was applied by dipping the base of the cuttings for 10 seconds. Then, the cuttings were disposed in perforate plastic boxes $(44 \times 30 \times 7 \mathrm{~cm})$ containing the different substrates.

The experiment was performed in a mist chamber with controlled intermittent timer and solenoid valve. The valve was programmed to mist during 10 seconds every three minutes. The nozzle nebulizer employed (Model DanSprinklers Mist, Israel) presents flow $35 \mathrm{~L} \mathrm{~h}^{-1}$. The mist chamber was maintained in greenhouse covered with transparent polyethylene film and 30\% shading. During the experiment, the mean maximum and minimum temperatures inside the greenhouse were of $32.1^{\circ} \mathrm{C}$ and $18.3^{\circ} \mathrm{C}$ respectively.

After 90 days, the following variables were evaluated: cutting rooting (\% of cutting which issued at least one major root), cutting survival (\% of alive cuttings); leaves retention ( $\%$ of cuttings that did not lose their leaves), number of roots per cutting, length of major roots per cutting $(\mathrm{cm})$ and dry weight of roots per cutting $(\mathrm{g})$. The root dry mass was obtained by drying in an oven with forced air at $78^{\circ} \mathrm{C}$ for $48 \mathrm{~h}$. After the completion of experiment, 
$\mathrm{pH}$ in water in a 1:1 ratio, the electrical conductivity (EC) $\left(\mathrm{mS} \mathrm{cm}^{-1}\right)$ the density $\left(\mathrm{kg} \mathrm{m}^{-3}\right)$ and the water retention capacity (WRC) $\left(\mathrm{mL} \mathrm{L}^{-1}\right)$ of the substrates were evaluated according to KÄMPF et al. (2006).

The data were submitted to analysis of variance and means were compared by Tukey test at $5 \%$ probability (BANZATTO \& KRONKA, 2006). The $\mathrm{pH}$, Electrical Conductivity (EC), density and Water holding capacity (WHC) of rice husk were $6.81,149.40\left(\mu \mathrm{S} \mathrm{cm}^{-1}\right), 161.20\left(\mathrm{kgm}^{-3}\right)$ and $466.80(\mathrm{~mL}$ $\left.\mathrm{L}^{-1}\right)$ respectively. The vermiculite and coconut fiber had $\mathrm{pH} 7.17$ and 6.53, EC 118.80 and $170.60\left(\mu \mathrm{S} \mathrm{cm}^{-1}\right)$, density 261.20 and $144\left(\mathrm{~kg} \mathrm{~m}^{-3}\right)$, WHC 396.40 and $790.40\left(\mathrm{~mL} \mathrm{~L}^{-1}\right)$ respectively.

\section{RESULTS AND DISCUSSION}

Several variables were significantly affected by both IBA and substrates. Cutting survival was significantly affected by substrate with maximum recorded in rice husk, followed by the vermiculite with minimum obtained by coconut fiber (Table 1). The lower survival in coconut fiber may be due to its higher water holding capacity which may cause the suffocation of cutting. The results are in line with CORREAA \& BIASI (2003), which stated that substrates with the improper aeration had higher percentage of dead cuttings and according to KAMPF (2000) that porosity of substrate has direct relation with cutting survival. However, IBA was not significant on the survival of the blackberry cuttings. BASTOS et al. (2006) reported that IBA increased the cutting rooting but had no significant affect on the cutting survival. YAMAMOTO et al. (2013) argued that IBA has no role in the survival of blackberry cuttings 'Xavante' when rice husk or vermiculite used as substrate when propagated in spring.

Leaves retention was significantly affected by both IBA and substrates tested. The impact of leaves retention had positive impact on the rooting and also on the new sprouts emergence, which in turn caused higher percentage of success. The leaves prepare carbohydrate through photosynthesis and also a small quantity of natural auxins present in the leaves helps in the rooting and sprouting of cuttings (HARTMANN et al., 1990).

Cuttings with new leaves were significantly affected by the substrates, however IBA had non significant effect. TIBERTI et al. (2012) narrate that cuttings treated with IBA may unbalance the naturally existing plant growth regulators present in the buds and leaves of cuttings, which in turn may cause variation for various variables like rooting and sprouting. The results are in accordance with VILLA et al. (2003), which found that sprouting and rooting percentage was higher when blackberry cuttings treated with $2,000 \mathrm{mg} \mathrm{L}^{-1}$ of IBA.

Rooted cuttings were significantly affected by both IBA and substrates (Table 1). RAMOS et al. (2003) reported that both indole butyric acid and substrate had significant effect on

Table 1 - Cutting survival, leaf retention, sprouted cuttings and rooted cuttings of 'Xavante' blackberry on different substrates and IBA doses.

\begin{tabular}{|c|c|c|c|c|}
\hline $\begin{array}{l}\text { Treatments } \\
\text { IBA (I) }\left(\mathrm{mg} \mathrm{L}^{-1}\right)\end{array}$ & Cutting survival (\%) & Leaves retention $(\%)$ & Cuttings with new leaves (\%) & Rooted cutting (\%) \\
\hline 0 & 65.0 & $46.7 \mathrm{~b}$ & 16.5 & $66.3 \mathrm{~b}$ \\
\hline 1,000 & 70.4 & $60.8 \mathrm{a}$ & 11.0 & $74.6 \mathrm{ab}$ \\
\hline 2,000 & 71.3 & $65.4 \mathrm{a}$ & 15.6 & $83.7 \mathrm{a}$ \\
\hline 3,000 & 65.0 & $57.1 \mathrm{ab}$ & 19.2 & $72.1 \mathrm{ab}$ \\
\hline $\mathrm{F}$ & $0.874 \mathrm{~ns}$ & $8.510 * *$ & $0.763 \mathrm{~ns}$ & $2.951^{*}$ \\
\hline \multicolumn{5}{|l|}{ Substrates (S) } \\
\hline Rice Husk & $82.5 \mathrm{a}$ & $65.0 \mathrm{a}$ & $14.3 \mathrm{ab}$ & $84.7 \mathrm{a}$ \\
\hline Vermiculite & $77.5 \mathrm{a}$ & $63.7 \mathrm{a}$ & $23.1 \mathrm{a}$ & $80.3 \mathrm{a}$ \\
\hline Coconut Fiber & $43.7 \mathrm{~b}$ & $43.7 \mathrm{~b}$ & $9.3 \mathrm{~b}$ & $57.5 \mathrm{~b}$ \\
\hline $\mathrm{F}$ & $45.192 * *$ & $25.297 * *$ & $4.230^{*}$ & $20.993 * *$ \\
\hline $\mathrm{F}(\mathrm{I} \times \mathrm{S})$ & $1.536 \mathrm{~ns}$ & $1.606 \mathrm{~ns}$ & $0.859 \mathrm{~ns}$ & $3.371^{*}$ \\
\hline $\mathrm{CV}(\%)$ & 18.47 & 16.49 & 87.28 & 16.60 \\
\hline
\end{tabular}

Means followed by the same letter are not significantly different at $5 \%$ level of significance by Tukey test. $\mathrm{ns}=$ non significant and $*=$ Significant at $5 \%$ level of significance.

$* *=$ Significant at $1 \%$ level of significance. 
the percentage of rooting, with a better performance of vermiculite in plum rootstock cv. 'Mirabolano'. YAMAMOTO et al. (2013) argued that vermiculite and the rice husk had the same positive affect for propagation of blackberry 'Xavante' on survival and rooting of cutting. The higher rooting in vermiculite and rice husk may be due to porosity which causes lower retention of water and higher air exchange than coconut fiber. SMARSI et al. (2008) argued that IBA and substrate had significant affect rooting and number of roots. MAIA \& BOTELHO (2008) state that among various IBA doses tested for rooting of blackberry cuttings, $2,000 \mathrm{mgL}^{-1}$ showed the best result.

It was observed significant difference using IBA in relation to the number of roots, however, the different substrates studied had no significant effect on the number of roots. PIO et al. (2005) stated that IBA influences the multiplication of blackberry, like number of roots and root length. MINAMI et al. (1994) reported that a good substrate is one that provides adequate conditions for roots development and growth.

The length of major roots was significantly affected by different substrate, with higher roots length was observed in vermiculite followed by rice husk with minimum in coconut fiber (Table 2). However, IBA was significant affected. FACHINELLO \& PAULETTO (1994) found that the formation of roots and roots system vary with each substrate, and with vermiculite, the performance is better than other substrates. HOFFMAN et al. (1995) studied various substrates and found that vermiculite has preference with other growth substrates. MARCO et al. (1998) stated that vermiculite is better than rice husk due to higher number of roots and rooting.

The dry weight of roots per cutting was significantly affected by different substrate, and the higher roots length was observed in vermiculite followed by rice husk, with minimum in coconut fiber. The results are in accordance with NICOLOSO et al. (1999), which stated that dry weight of roots has a direct relation with the substrate used for the propagation.

The results indicate that the development of rooting cutting, number and length of major roots were higher in vermiculite and rice husk and lower in coconut fiber. IBA $2,000 \mathrm{mg} \mathrm{L}^{-1}$, a root promoting plant growth regulator is considered a better option for enhancement of roots in blackberry cutting.

\section{CONCLUSION}

For blackberry 'Xavante' cutting rooting, both rice husk and vermiculite can be used along $2,000 \mathrm{mg} \mathrm{L}^{-1}$ of IBA.

\section{ACKNOWLEDGEMENTS}

\author{
The authors thank Conselho Nacional de \\ Desenvolvimento Científico e Tecnológico (CNPq) and TWAS for \\ financial support.
}

Table 2 - Number of roots per cutting, major length, and dry weight of roots per cutting of 'Xavante' blackberry on different IBA doses and substrates.

\begin{tabular}{llll}
\hline Treatments & Number of roots per cutting & Length of major root $(\mathrm{cm})$ & Dry weight of roots per cutting (g) \\
IBA (I) $\left(\mathrm{mg} \mathrm{L}^{-1}\right)$ & & & 0.4 \\
\hline 0 & $8.7 \mathrm{~b}$ & 27.7 & 0.5 \\
1,000 & $11.3 \mathrm{ab}$ & 27.3 & 0.5 \\
2,000 & $13.5 \mathrm{a}$ & 27.1 & 0.4 \\
3,000 & $11.1 \mathrm{ab}$ & 23.0 & $0.691 \mathrm{~ns}$ \\
F & $3.260^{*}$ & $1.599 \mathrm{~ns}$ & $0.4 \mathrm{ab}$ \\
Substrate (S) & & & $0.5 \mathrm{a}$ \\
Rice Husk & 11.1 & $30.4 \mathrm{a}$ & $0.3 \mathrm{~b}$ \\
Vermiculite & 12.2 & $32.1 \mathrm{a}$ & $16.5 \mathrm{~b}$ \\
Coconut Fiber & 10.2 & $31.163 * *$ & $6.828^{*}$ \\
F & $1.244 \mathrm{~ns}$ & $0.395 \mathrm{~ns}$ & $1.772 \mathrm{~ns}$ \\
F (I x S) & $0.732 \mathrm{~ns}$ & 23.44 & 41.71 \\
CV $(\%)$ & 32.99 & & \\
\hline
\end{tabular}

Means followed by the same letter are not significantly different at $5 \%$ level of significance by Tukey test.

$\mathrm{ns}=$ non significant and $*=$ significant at $5 \%$ level of significance.

$* *=$ Significant at $1 \%$ level of significance. 


\section{REFRENCES}

ANTUNES, L.E.C. Amora-preta: nova opção de cultivo no Brasil. Ciência Rural, Santa Maria, v.32, n.1, p.151-158, 2002. Available from: <http://www.scielo.br/pdf /cr/v 32n1/a26v32n1. pdf>.Accessed: Aug. 28, 2013.

ANTUNES, L.E.C. et al. Propagação, plantio e tratos culturais. In: ANTUNES, L.E.C.; RASEIRA, M.C.B. Aspectos técnicos da cultura da amora-preta. Pelotas: Embrapa Clima Temperado, 2004. 54p. (Embrapa Clima Temperado Documentos 122).

ANTUNES, L.E.C. et al. Propagação de cultivares de amoreirapreta (Rubus spp) através de estacas lenhosas. Revista Brasileira de Fruticultura, Jaboticabal, v.22, n.2, p.195-199, 2000.

BANZATTO, D.A.; KRONKA, S.N. Experimentação agrícola. 4. ed. Jaboticabal: UNESP, 2006. 237p.

BASTOS, D.C. et al. Tipo de estaca e concentração de ácido indolbutírico na propagação da lichieira. Ciência Agrotecnologia, Lavras, v.30, n.1, p.97-102, 2006

CORRÊA, C.; BIASI, L. Área foliar e tipo de substrato na propagação por estaquia de cipó-mil-homens (Aristolochia triangularis CHAM. ET SCHL.). Revista Brasilera Agrociência, Pelotas, v.9, n.3, p. 233-235, 2003. Available from: <http://www.ufpel.tche.br/faem/ agrociencia/v9n3/artigo08.pdf>. Accessed: Jul. 13, 2013.

FACHINELLO, J.C.; PAULETTO, E.A. Influência do substrato sobre o enraizamento de estacas semi lenhosas de figueira e araçazeiro. Revista Brasileira de Fruticultura, Cruz das Almas, v.16, n.1, p. 302-307, 1994. Available from: <http://www.scielo.br/ scielo.php? script=sci arttext\&pid=S0100-29452008000200003 >. Accessed: Jul. 12, 2013. doi:10.1590/S0100-29452008000200003.

FACHINELlO, J.C. et al. Propagação de plantas frutíferas. Brasília: Embrapa Informações Tecnológicas, 2005. 221p.

FAO. Agriculturalstatistics. 2013. Available from: <www.faostat. fao.org/site/567/DesktopDefault.aspx?PageID=567\#ancor $>$. Accessed: Apr. 9, 2013.

HARTMANN, H. et al. Plant propagation: principles and practices. 5.ed. Englewood Cliffs: Prentice Hall, 1990. 647p.

HAN, H. et al. A review on the molecular mechanism of plants rooting modulated by auxin. African Journal of Biotechnology, Kenya, v.8, n.3, p.348-353, 2009.

KAMPF, A.N. Produção comercial de plantas ornamentais Guaíba: Agropecuária. 2000. 254p.

KAMPF, A.N. et al. Floricultura: técnicas de preparo de substratos. Brasília: LK, 2006. 132p.

MARCO, C.A. et al. Influência do ethephon e do ácido indole butaríco no enriazamento de estacas de ramos de Goibera (Psidium guajava). Ciência Rural, Santa Maria v.28, n.2, p.221-224, 1998. Available from: <http://www.scielo.br/pdf/cr/v28n2/a06v28n2. pdf $>$. Accessed: Jan. 11, 2013.

MAIA, A.J.; BOTELHO, R.V. Plant regulators for rooting of hardwood cuttings of blackberry plants cv. 'Xavante' Ciência
Agrárias, Londrina, v.29, n.2, p.323-330, 2008. Available from: <www.uel.br/revistas/uel/index.php/article/2399>. Accessed: May.3, 2014

MINAMI, K. et al. Produção de mudas hortícolas de alta qualidade. Piracicaba: ESALQ/SEBRAE, 1994. 155p.

NICOLOSO, F.T. et al. Influência da osição da estaca no ramo sobre o enraizamento de Pfaffia glomerata (Spreng.) Pedersen em dois substrato. Ciência Rural, Santa Maria, v.29, n.2, p.277-283, 1999. Available from: <http://www.scielo.br/scielo.php?pid=S010384781999000200015\&script=sci_arttext $>$. Accessed: Jul. 6, 2013. doi:10.1590/S0103-8478199900 0200015 .

PIO, R. et al. Rooting of different types of olive (Olea europaea L.) tree cuttings using indol butyric acid Ciência Agrotecnologia, Lavras, v.29, n.3, p.562-567, 2005. Available from: <http://www. scielo.br/pdf/cagro/v29n3/a08.pdf>. Accessed: Jul.11, 2013.

POPINIGIS, F. Fisiologia de sementes. Brasília: AGIPLAN, 1977. 289p.

RAMOS, J.D. et al. Enraizamento de estacas herbáceas de 'Mirabolano' (Prunus cerasifera Ehrn) em diferentes substratos. Revista Brasileira de Fruticultura, Jaboticabal, SP, v.25, n.1, p.189-191, 2003. Available from: <http://www.scielo.br/pdf/rbf/ v25n1/a53v25n1.pdf>. Accessed: Jul. 11, 2013.

RASEIRA, M.C.B. et al. Classificação botânica, origem e cultivares. In: ANTUNES, L.E.C.; RASEIRA, M.C.B. Aspectos técnicos da cultura da amora-preta. Pelotas: Embrapa Clima temperado, 2004. 54p.

SMARSI, R.C. Concentrações de ácido indolbutírico e tipos de substrato na propagação vegetativa de lichia. Revista Brasileira de Fruticultura, Jaboticabal, SP, v.30, n.1, p.7-11, 2008. Available from: 〈http://www.scielo.br/pdf/rbf/v30n1/04.pdf> Accessed: Jun. 15, 2013

TIBERTI, A.S. et al. Propagação do 'Boysenberry' por estaquia e mergulhia. Ciência Rural, Santa Maria, v.42, n.3, p.423-428, 2012. Available from: <http://www.scielo.br/sci elo.php?pid=S010384782012000300007\&script=sci_arttext $>$. Accessed: Jul. 11, 2013. doi: 10.1590/S0103-84782012000300007.

VILLA, F. et al. Propagação de amoreira-preta utilizandose estacas lenhosas. Ciência Agrotecnologia, Lavras, v.27, n.4, p.829-834, 2003. Available from: <http://www.scielo. br/scielo.php? pid $=$ S 1413-70542003000400013\& script $=$ sci arttext>. Accessed: Jul. 13, 2013. doi: 10.1590/S141370542003000400013

YAMAMOTO, L.Y. et al. Substratos no enraizamento de estacas herbáceas de amora-preta Xavante. Ciência Rural, Santa Maria, v.43, n.1, p.15-20, 2013. Available from: <http://www.scielo.br/ pdf/cr/v43n1/a1713cr2012-0499.pdf >. Accessed: Jul. 7, 2013.

ZIETEMANN, C.; ROBERTO, S.R. Efeito de diferentes substratos e épocas de coleta no enraizamento de estacas herbáceas de goiabeira,cvs. paluma e século XXI. Revista Brasileira de Fruticultura, Jaboticabal, v.29, n.1, p.31-36, 2007. Available from: <http://www.scielo.br/scielo.php?pid=S010384782010000500006\&script=sci_arttext $>$. Accessed: Jul. 13, 2013. doi:10.1590/S0103-84782010000500006. 